\title{
AS-SUNNAH SEBAGAI SUMBER HUKUM ISLAM: REFLEKSI TERHADAP HERMENEUTIKA MUHAMMAD SYAHRUR
}

\author{
Muhazir $^{*}$
}

\begin{abstract}
In recent years many studies have developed from both groups who doubt the authenticity of the Sunnah and the power of Sunnah as a source of Islamic law. This problem inspires Muslim scholars who consider that the group's doubts are due to the weakness of the study and the approach taken by the previous ulama as well as academic re-examination, the shahrur is a figure of Muslim scholars seeking hermeneutical methods so that the hadith still has original value and is accountable for academic value.
\end{abstract}

\section{Keywords: As-Sunnah, Islamic Law, Hermeneutical}

\section{PENDAHULUAN}

Sunnah merupakan sumber hukum kedua bagi ummat Islam dunia, tidak dipungkiri lagi bahwa kekuatan sunnah sangat penting dalam memahami hukum Islam yng bersumber dari al-Quran, karena sunnah memiliki fungsi sebagai penjelas al-quran. Al-Quran dengan segenap keistimewaannya memiliki kandungan sastra bahasa yang terkadang sulit untuk dipahami secara tekstual. Oleh karena itu, pendekatan kebahasaan merupakan salah satu syarat penting dalam memahami sumber hukum Islam, kemampuaan dalam memahami bahasa merupakan syarat utama dalam memahami makna kata dalam al-Quran dan As-Sunnah.

Perdebatan tentang konsepsi sunnah hingga sekarang masih hangat diperbincangkan, mulai dari kalangan ulama, cendikiawan muslim hingga tokoh orentalis, tidak menutup kemungkinan bahwa kajian sunnah memiliki ragam konsen pendekatan metodologis yang berbeda-beda, sebenarnya hal ini akan membuktikan bahwa sunnah yang diragukan oleh

* Penulis adalah Dosen Tetap Fakultas Syariah IAIN Langsa, Email: muhazir@iainlangsa.ac.id 
kaum orientalis memiliki akar yang tidak logis baik secara metodologis maupun substantif.

Berbeda dengan tokoh revormis lainnya, Syahrur lebih memfokuskan diri dalam kajian sunnah dengan pendekatan lingguistik, karena kebanyakan para tokoh muslim terpaku kepada makna teks yang terkadang terjadi kesalah pahaman dan lebih dari pada itu, konsep sunnah perspektif Syahrur memiliki konsen yang berbeda, Syahrur telah membagi sunnah kedalam beberapa konsep.

\section{BIOGRAFI MUHAMMAD SYAHRUR}

Dr.Ir. Muhammad Syahrur ibn Daib lahir di Damaskus, Syiria, 11 April 1938. pendidikannya diawali di sekolah Ibtidaiyah, Iddadiyah dan Tsanawiyah, di Damaskus. Syahrur memperoleh ijazah Sanawiyah di Abdurrahman al-kawakib (1957). pada tahun 1958 dengan beasiswa dari pemerintah Damaskus, Syahrur hijrah ke Uni Soviet untuk studi teknik sipil di Moskow dan menyelesaikan diplomanya pada 1964. di tahun 1965, syahrur kembali ke Syiria dan mengajar di Universitas Damaskus. Kemudian oleh pihak universitas, ia dikirim ke Irlandia untuk studi pascasarjana dalam spesialisasi mekanika tanah dan teknik fondasi pada Ireland National University. Gelar Master of Science diperoleh pada 1969, dan gelar Doktor pada 1972. Syahrur, hingga sekarang, masih tetap tercatat sebagai tenaga edukatif pada fakultas teknik sipil Universitas Damaskus tersebut dalam bidang mekanika tanah dan geologi (Muhammad Syahrur, 2002: 1).

Latar belakang dengan keilmuan tehniknya tidak menggoyahkan keilmuannya tentang hadis dan al-quran, fase awal (1970-1980) setelah selesai program magister dan doktornya dalam bidang tehnik sipil, pada fase ini adalah dimana syahrur mulai melakukan kontenplasi dan meletakkan pemahaman dasar tentang al-quran sebagai az-zikr, pada fase ini syahrur mengalami kegelisahan tentang memahami konsep al-quran serta sikan al-quran dan hadis dalam mandang perubahan zaman serta kegelisahannya juga disebabkan karena sikap taklid yang diwarisi oleh ulama mazhab yang diajarkan dimadrasah, disamping cenderung kepada islam yang berfungsi sebagai idiologi baik dalam bentuk kalam maupun mazhab pada saat itu, hal yang seperti ini yang mempengaruhi fazlur untuk memiliki semangat mengkaji sumber-sumber hukum islam.

Pada 1980, Syahrur bertemu dengan teman lamanya Dr.ja'far (yang medalami studi bahas di Uni soviet antara tahun 1958-1964). Dalam kesempatan tersebut, syahrur menyampaikan tentang perhatiannya besarnya terhadap studi bahasa, filsafat dan pemahamannya terhadap alQur'an. Kemudian syahrur menyampaikan pemikiran dan disertasinya di 
bidang bahasa yang disampaikan di universitas moskow pada 1973. topic disertasinya mengenai pandangan linguistik abd al-Qadir al-Jurhani (ahli nahwu dan balaghah) dan posisinya dalam linguistic umum. Lewat Ja'far, syahrur belajar banyak tentang linguistik termasuk filologi, serta mulai mengenal pandangan-pandangan al-Farra', Abu Ali al-Farisi serta muridnya, Ibnu Jinni dan al-Jurhani. Sejak itu, syahrur berpendapat bahwa sebuah kata memiliki satu makna dan bahasa arab merupakan bahasa yang di dalamnya tidak terdapat sinonim. Selain itu, antara nahwu dan balaghah tidak dapat dipisahkan, sehingga menurutnya, selama ini ada kesalahan dalam pengajaran bahasa arab di berbagai madrasah dan universitas.

Sejak itu pula, ia mulai menganalisis ayat-ayat al-Qur'an dengan model analisis baru. Dan pada tahun 1984, ia mulai menulis pokok-pokok pikirannya bersama ja'far yang digali dari al-kitab ((Muhammad Syahrur, 2002: 2). Sebenarnya kegelisahan akademisinya yang berkaitan dengan eksistensinya di Moscow yang pada saat itu dikenal dengan degara komunis, disitu syahrur melihat banyak hal yang berbenturan dengan konsep-konsep idiologi islam, dan disini pula Syahrur mengagumi pemikiran marxisme dan filosof asal jerman yaitu Hegel, dari perbenturan cultural tersebut mengakibatkan syahrur yang cenderung berbeda dan kontradiktif, membawa syahrur untuk lebih memahami tentang indiologi islam dengan mengawalinya dari sumber hukum yaitu al-quran dan hadis. Selain menjadi tenaga pengajar difakultas tehnik sipil universitas damaskus dibidang mekanik tanah dan dasar bumi, ia juga belajar berbagai ilmu keagamaan untuk menambah keilmuannya dalam mengkaji ilmu keislaman, ilmu-ilmu agama yang dipelajari seperti ilmu fiqh, lughah dan kesustraan bahasa baik bahasa arab dan bahasa ingris serta rusia, dan ia juga belajar ilmu filsafat yang dari proses belajarnya inilah dia lebih kagum kepada tokoh filsafat dari jerman tersebut. Dalam mengkaji ilmu al-quran dan hadis ia menggunakan pendekatan filsafat bahasa dan dikolaborasikan dengan teori eksaktanya (Sahiron Syamsuddin, 2010: 287-288) adapun teori yang sangat dikenal dikalangan scholer Islamic studies yaitu tentang nazariyyah al-budu (Sahiron Syamuddin, 2003: 141-173).

Muhammad syahrur bukan saja sepagai seorang yang dijuluki pemikir kontemporer lebih dari itu dia juga termasuk tokoh yang produktif dalam mengkaji islam hal ini terbukti dengan beberapa karangan melalui tulisannya tentang keislaman seperti, Al-Kitab wa Al-Quran : Qira'ah Mu'asirah, Dirasah Islamiyyah Mu'asirab Fi Ad-Dawlah wa Al-Mujtama'(1994), Al-Islam wa Al-Iman : Manzumat Al-Qiyam (1996). Masyru' misaq al-amal alislami. Nabwa usul jadidah li al-fiqh al-islami selain itu ia juga suka menulis artikel dimajalah dan jurnal antara lain artikel dengan judul " the devine texs and pluralism in moslem societies" (Sahiron Syamuddin, 2003: 124-125). dan 
"Islam and the 1995 Beijing World Conference on Woman",dalam, Kuwaiti Newspaper, dan kemudian dipublikasikan juga dalam, Charles Kurzman (ed.), Liberal Islam: A Sourcebook (New York \& Oxford: Oxford University Press,1998).

\section{Hermeneutika As-Sunnah Perspektif Muhammad Syahrur}

Melihat dari background akademisinya bagaimana kolaborasi keilmuan teknik dan agama dipadu dalam satu metode pemahaman dengan nalar kritis terhada sumber hukum islam hal inilah yang membedakan antara Syahrur dengan intelektual islam lainnya, memang dalam perjalanan akademisinya ia tidak mendalami dan menekuni bahasa arab secara detail, namu ketika ia menyampaikan pemikirannya tentang kajiannya ia menggunakan metode historis ilmiah, meskipun ia tidak mendetai membahasnya, namun lebih jauh lagi metode yang digunakan oleh syahrur dalam memahami sumber hukum islam menurut Abu Al-Farisi dilandasi oleh prinsip dasar antara lain (Sahiron Syamuddin, 2003: 126);

1. Bahasa merupakan sebuah sistem

2. Bahasa memiliki hubungan fenomenologis sehingga perubahan bahasa sangat berpengaruh terhadap konteks pada masa tersebut.

3. Bahwa bahasa memiliki keterkaitan yang kuat dengan pemikiran.

Dari beberapa prinsip dan diikuti dengan metode yang dipromototi oleh syahrur Nampak jelas bahwa Syahrur lebih cenderung memahami teks hukum secara lingguistik (kebahasaan) dalam artian bahwa selain ia menggunakan pendekatan kebahasaan ia juga menggunakan histori pada saat teks itu hadir dengan padanan konteks sekarang. Namun serasionalnya syahrur ia juga tidak lepas dari bingkaian keilmuan Muhammad 'Abid Al-Jabari dengan pola bayani yang merupakan keilmuan yang titik fokusnya berangkat dari teks. Dalam karya nya seperti " al-kitab wa al-quran :qira'atu mu'asyarah" syahruh lebih banyak berkutik dalam teks (nas) yang bersifat umum begutiu juga dalam hadis ia lebih banyak mengkaji hadis dalam term umum dan mengkritisi ulasan ulama klasik terkait tentang term umum seperti iman, rukun islam dan rukun iman dan lainnya.

Berbeda dengan ulama klasik yeng menyamakan hadis dan sunnah secara umum ulama klasik menjabarkan bahwa Kata "Hadits" atau "alhadîth" secara etimologisnya berarti al-jadîd sesuatu yang baru atau juga berarti al-qarîb dekat, atau al-kalâm pembicaraan tentang sesuatu. Menurut jumhur ulama Hadits bahwa tidak ada perbedaan makna antara Hadits dan sunnah, sebab kedua-duanya berasal dari nabi Muhammad saw. Oleh 
karena itu,mereka mendefinisikan Hadits atau sunnah sebagai berikut :

$$
\text { آَوَوَالُ النبي ص م و افعالهُ وَاَحْوَا لُهُ }
$$

Artinya : "Segala perkataan Nabi, perbuatan, dan hal ihwalnya."

Berbeda dengan pendapat di atas, Syahrûr menyatakan bahwa Hadits adalah kehidupan Nabi Muhammad saw sebagai seorang nabi (pembawa berita) dan manusia yang hidup dalam dunia nyata bukan dialam imajinasi, Jadi Hadis merupakan hasil interaksi beliau dengan kejadian-kejadian tertentu dalam situasi tertentu pula pada masa beliau hidup (produk sejarah). Dengan demikian, Hadis bukanlah wahyu dari Allah swt, sebab Nabi saw dan para sahabat tidak menganggap Hadis sebagai wahyu.Halini terbukti bahwa baik nabi maupun para sahabat tidak pernah memerintahkan untuk mengumpulkan dan menulis Hadits.

Adapun sunnah menurut Syahrûr berarti mudah. Sebab, kata sunnah berasal Dari kata "sanna" yang berarti mudah, sebagaimana dikatakan" ma'un mas'nun" yang berarti air yang mengalir dengan mudah dan lancar. Menurutnya, pengertian ini sesuai dengan prinsip dasar ajaran Islam yaitu membawa kemudahan bagi umatnya. Syahrur menegaskan lagi bahwa sunnah yaitu metodologi penerapan hukum atau Al-Kitab yang mencakup persoalan budud serta perbuatan batasan-batas local yang bersifat non-hudu dengan mempertimbangkan realitas nyata, waktu, tempat serta kondisi dimana hukum tersebut akan diterapkan. Dalam konteks lain Syahrur mendifinisikan bahwa sunnah adalah ijtihad nabi dalam menerapkan hukum-hukum al-kitab yang berupa budud, ibadah dan akhlak dengan bergerak diantara batasan-batasan dan menciptakan batasan temporal bagi persoalan yang belum ada pada saat itu (Sahiron Syamuddin, 2003: 397).

Selanjutnya Syahrûr mengklasifikasikan sunnah kepada sunnah $A l$ Nubuwwab dan Sunnah al-Risalah. Adapun sunnah nubuwwah yaitu sunnah yang menyangkut keilmuan nabi tentang ilmu-ilmu alam seperti falaq dan keilmuan tentang manusia serta tentang alam ghaib seperti penjelasan tentang kehidupan diakhirat dan lain sebagainya sedangkan sunnah risalah yang berkaitan dengan hukum-hukum islam seperti puasa, shalat, haji, dan lainnya (Online, 2018).

Kajian tentang sunnah selalu berkaitan tentang nabi karena secara umu dikalangan para ulama hadis memahami hadis sebagai segala sesuatu yang disandarkan kepada nabi dalam makna lebih luas yang bersumber dari nabi(Daniel Juned, 2010: 78), menurut syahrur tentang kenabian, bahwa nabi bertugas mengubah yang mutlak menjadi yang nisbi yang bergerak dalam bingkaian pengawasan allah atau pada masa kenabiannya di semenanjung arab dan inilah kebenaran dan hakikat sunnah Nabi dalam 
posisi ini nabi merupakan seorang mujtahid yang mengkonstruk dari yang bersifat teks menjadi aplikatif. Konsep ini serupa dengan konsep yang ditawarkan oleh Hegel dengan teori absolutnya tentang islam, menurut hegel susunan rasional atas sifat yang absolute dalam artian nabi merupakan interpretative hukum-hukum ilibiyah yang dituangkan kedalam realitas nisbi ((Sahiron Syamuddin, 2003: 395).

Terkait tentang ralasi antara amaliayah nabi dalam non-ibadah, nonghaib dan hukum apakah merupakan wahyu atau ijtihad, dalam hal ini Syahrur berpendapat bahwa jika dikaitkan dalam konteks tersebut maka ijtihad nabi bukan wahyu, lebih lanjut syahrur menjelaskan tentang ayat alquran dalam Surat An-Najm ayat 3-4 :

"dan tiadalah yang diucapkannya itu (Al Qur'an) menurut kemauan hawa nafsunya. Ucapannya itu tiada lain hanyalah wahyu yang diwahyukan (kepadanya)'.

Ayat ini dipakai dalil yang digunakan untuk melegitimasi bahwa apa yang dikatakan oleh nabi adalah wahyu. Dari ayat tersebut menurut syahrur bukanlah perkataan nabi melainkan merujuk kepada al-quran lebih lanjut Syahrur menjelaskan bahwa dhamir ya pada lafalz yantiqu merujuk kepada al-quran bukan Nabi. Selanjutnya menurut syahrur bahwa yant tersebut turun dimakkah di mana orang arab meragukan akan kebenaran al-quran sebagai tatanan baru, bukan meragukan akan kebenaran perkataan nabi, jadi menurutnya ayat tersebut tidak berkaitan dengan nabi melainkan berkaitan dengan kebenaran al-quran sebagai wahyu, berangkat dari konsep Islam absolute dan islam nisbi bahwa dalam aspek pemahaman nisbi diluar persoalan budud dan perkara yang berhubungan dengan non ibadah bukanlah wahyu. Secara tegas syahrur menegaskan bahwa hadis dan sunnah bukanlah wahyu, lebih jelas lagi syahrur mengatakan bahwa hadis rasul tidak bersifat mutlaq yang bersifat mutlaq yaitu firman allah (al-quran), lanjutnya yang harus ditaati pada nabi yaitu yang bersifat hukum-hukum, ibadah serta akhlaq, karena menurut syahrur kehidupan nabi dipengaruhi oleh politik, budaya, ekonomi serta sosiocultural pada masa itu (abad $7 \mathrm{H})$.

Pernyataan yang dianggap liberalis bagi kelompok yang kontra bahwa Menurut syahrur kehidupan nabi merupakan sebuah bentuk percontohan bagi umat islam yang melandasi hidup sesuai dengan apa yang diperintahkan oleh allah, kehidupan nabi merupakan model kehidupan muslim yang pertama, begitu juga selanjutnya bahwa kita memang harus menghargai, menghormati mengagungkan Nabi Muhammad dan para sahabat nabi bukan berarti kita harus mengangung agungkan penafsiran mereka terhadap sumber-sumber hukum islam, jadi 
wajar saja bagi golongan yang menentang gagasan syahrur ini dengan mengatakan bahwa syahrur adalah "an enemy of Islam" atau "a western zionist agent".

Kembali lagi tentang permasalahan macam-macam sunnah, menurut syahrur Sunnah Nubuwwah dibagi lagi menjadi dua macam yaitu. Pertama, sunnah yang berhubungan dengan hal-hal ghaib dan pemahaman umum tentang al-quran bukan berarti mentakwilkan al-quran karena posisi nabi bukan sebagai pentakwil. Kedua yang berhubungan dengan uraian bersifat informative belaka dan tidak harus dita'ati. Diantara sunnah nubuwwah tersebut ada yang bersifat relevan dengan konstruk zaman sekarang, dan dalam kondisi seperti ini dapat kita ambil dan dapat juga tidak diambil. Jadi dapat digambarkan :

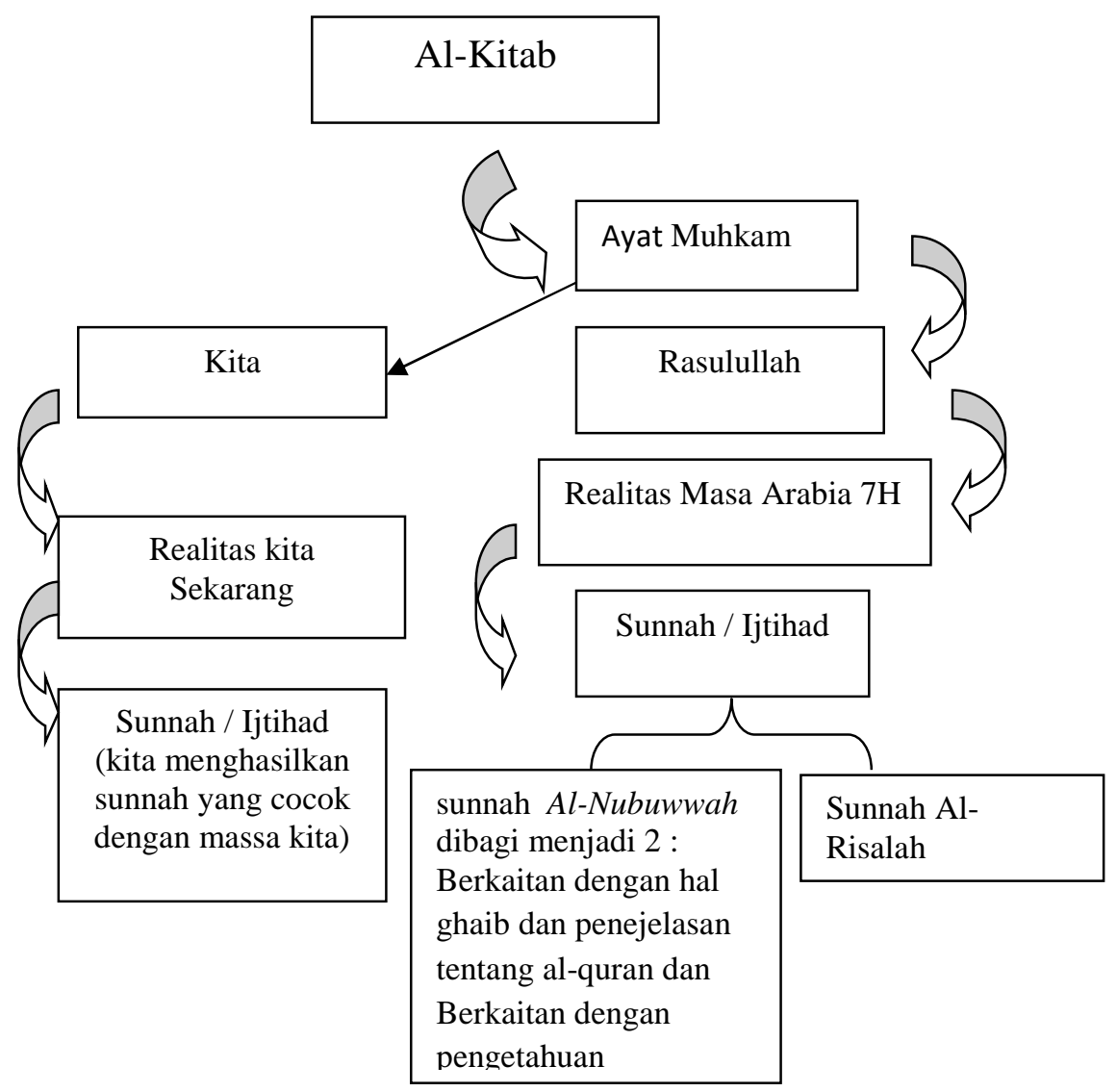

Gambar1. Alur Pemahaman Sunnah Al-Nubuwwah 
Dilihat dari konsep sunnah perspektif Syahrur tersebut maka syarur memahami bahwa posisi nabi sebagi mujtahid, syahrur membatasi rasullah sebagi orang yang ma'sun hanya dalam dua tatanan saja yaitu dalam penyampaian adz-ijkr dan pada ummatnya dalam hal haram dan halal. Hanya dalam hal inilah nabi benar-banar terjaga kema'sumannya, sehingga lebih lanjut syahrur mengatakan bahwa ijtihad nabi pada ayat-ayat hukum tidaklah ma'sum, ijtihad nabi hanyalah benar pada masanya saja dan ijtihad rasul belum tentu sesuai dengan zaman kita. Tatapi perlu diketahui bahwa rasul berijtihad dalam wilayah penetapan hukum tasyri' baik dibidang politik, muamalah dan hubungan social lainnya, bukan dalam wilayah syi'ar sy'ar bukan pula diwilayah etika.

Ada beberapa kritkan syahrur terhada generasi ulama-ulama klasik yang melakukan pembakuan pemahannya terkait dengan rukun islam, dalam hadisnya nabi yang diriwayatkan oleh bukhari bahwa "islam dibangun diatas lima perkara"

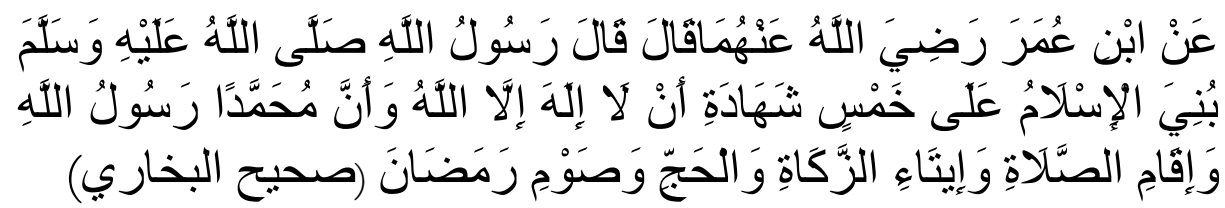

yang kemudian oleh generasi ulama' menyimpulakan bahwa rukun islam ada lima perkara, menurut syahrur hal ini tidaklah sesuai karena ada hadis-hadis lainnya yang menjelaskan tentang apa itu Islam (Muhammad Syahrur, 2002: 21).

1. Memberi makan orang lain adalah sebaik-baiknya amalan islam (Al-Bukhari No 12.)

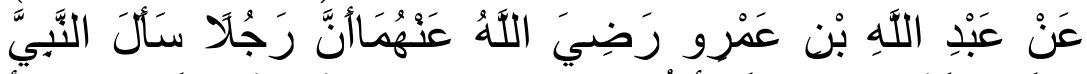

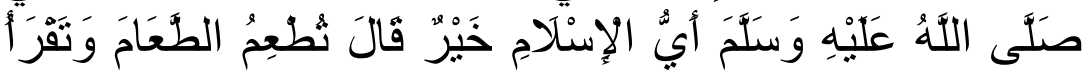

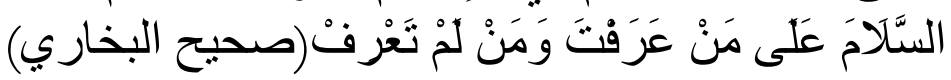

2. Menyebarkan salam adalah sebaik-baiknya amalan islam (AlBukhari No 28).

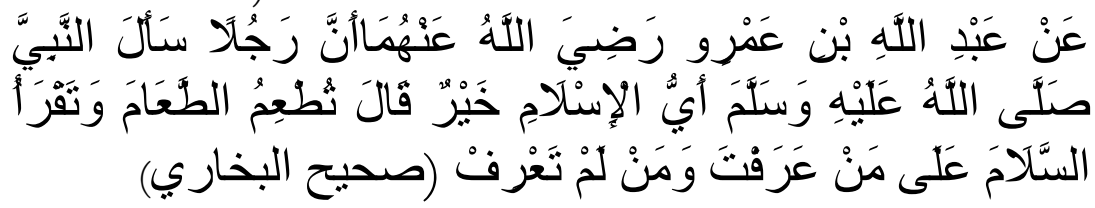

3. Nasihat adalah bagian dari agama/ islam (Al-Bukhari No 85). 


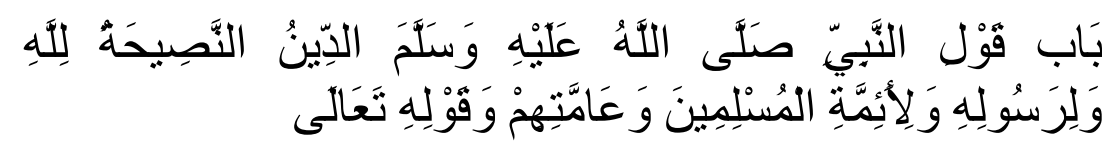

Hal ini menjelaskan bahwa Islam itu luas tidak hanya dengan 5 perkara tersebut saja. Secara objektif Syahrur juga menegaskan bahwa persoalan ritual dan akhlaq kita menta'atinya secara muttasil sedangkan yang berkaitan dengan tasyri' kita menta'atinya secara munfasil, dari keterangan tersebut memberikan pemahaman baru tentang konsep keta'atan syahrur terhadap rasulullah saw. Ketaatan muttasil sama halnya keta'atan kita kepada allah tidak pernah putus hal ini seperti shalat, zakat, puasa dan haji, sedangkan yang munfasil ketaatan yang berbeda ketika nabi masih hidup dan sesudah nabi wafat dalam artian setelah nabi wafat kita menta'ati nabi secara metodologi (manhaji) dalam hal metode ijtihad nnabi saja hal ini bersifat tempotal atau local dan kondisi ini disesuaikan olen nabi dengan masa nabi hidup (Sahiron Syamuddin, 2003: 407).

\section{Kesimpulan}

Muhammad Syahrur merupakan salah satu cendikiawan muslim yang keilmuannya dan ketertarikannya kepada kajian keislaman membawa syahrur kedalam penggalian kembali terhadap konsep hadis yang telah lebih dahulu dikaji da dirumuskan oleh para ulama-ulama hadist. Meski begitu, Syahrur dengan kegelisahan akademisnya berusaha ingin membahas lagi konsep sunnah yang dianggap oleh mayoritas muslim sudah menjadi sakral dan tidak dapat diganggu gugat lagi.

Syahrur berusaha memahami hadis dengan metode lingguistik dengan menelaah term hadis dan sunnah, adapun metode yang digunakan yaitu : Pertama, Bahasa merupakan sebuah sistem. Kedua, Bahasa memiliki hubungan fenomenologis sehingga perubahan bahasa sangat berpengaruh terhadap konteks pada masa tersebut. Ketiga, Bahwa bahasa memiliki keterkaitan yang kuat dengan pemikiran.

\section{DAFTAR PUSTAKA}


Atir. Nuruddin .'Manbaj Al-Naqdi Fi 'Ulumi Al-Hadis. ( Beirut : Dar AlFiqr, 1997)

Daniel Juned. Ilmu Hadis. (Jakarta : Erlangga,2010)

Online (2018). http:/ / ejournal.sunan-ampel.ac.id. Diakses 12 Juli 2018

Syahrur, Muhammad, Islam dan Imam. trj M.Zaid Su'di. (Yogyakarta : jendela, 2002).

Syamsudin, Sahiron, et.al. Hermenentika Al-Quran Mą̧ab Yogya. (Yogyakarta : Islamika,2003)

Syamsuddin, Sahiron. Pemikiran Hermeneutika Dalam Tradisi Barat Reader. (Yogyakarta : Lembaga Penelitian UIN Sunan Kalijaga, 2011) (Yogyakarta, Elsaq Press, 2010) 